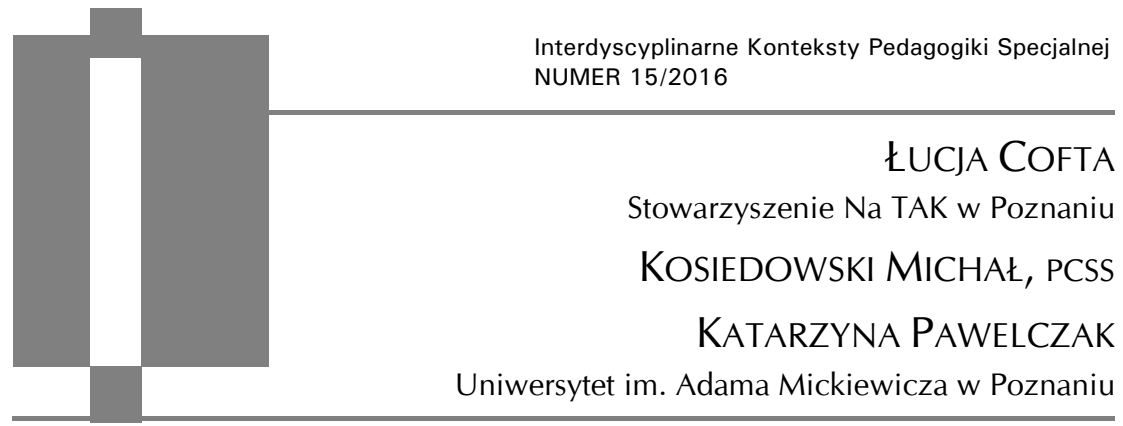

\title{
Sprawozdanie z konferencji "The Meaning of Professional in an Era of Change" AAIDD 140th Annual Meeting", American Association on Intellectual and Developmental Disabilities, 6-9 czerwca 2016 r., Atlanta, GA, USA.
}

Amerykańskie Stowarzyszenie Niepełnosprawności Intelektualnej i Rozwojowej (AAIDD - The American Association on Intellectual and Developmental Disabilities), działające w Stanach Zjednoczonych od 1876 r., jest najstarszą interdyscyplinarną organizacją skupiającą specjalistów zaangażowanych w działania na rzecz osób z niepełnosprawnością intelektualną. AAID to społeczność złożona z ponad 5000 członków w 55 krajach, w skład której wchodzą eksperci dysponujący bogatym doświadczeniem w zakresie medycyny, pedagogiki, psychologii, pracy socjalnej i rehabilitacji. Stowarzyszenie jest inicjatorem przemian w dziedzinie studiów i badań nad niepełnosprawnością intelektualną. Mowa tu o zmianie paradygmatu (ang. paradigm shift), perspektywy ujmowania ID (ang. intellectual disability) z opartej na deficytach, na - jak określa to Deborah Deutsch Smith ${ }^{1}$ " „bardziej pozytywną", uwypuklająca zależności między zdolnościami osoby a środowiskiem życia i jakością otrzymywanego wsparcia. AAIDD jest także organizatorem cyklicznych spotkań środowisk zaangażowanych w działa-

${ }^{1}$ D.D. Smith, Pedagogika specjalna, PWN, Warszawa 2008, s. 225. 
nia na rzecz wspierania osób z niepełnosprawnością intelektualną. Mają one charakter międzynarodowy i realizowane są $\mathrm{w}$ formule tematycznych konferencji sesyjnych. Odbywają się rokrocznie w poszczególnych regionach Stanów Zjednoczonych, gromadząc specjalistów do spraw opieki, diagnostyki i wsparcia a także członków rodzin, self-adwokatów, badaczy reprezentujących wiele ośrodków uniwersyteckich. Są miejscem wymiany doświadczeń i rozwiązań praktycznych, które służą podnoszeniu jakości życia osób z niepełnosprawnością intelektualną. W 2016 r. w stanie Georgia, w Atlancie, w dniach 6-9 czerwca odbyło się 140. już spotkanie. Tematem przewodnim konferencji był profesjonalizm działań kierowanych ku osobom z niepełnosprawnością intelektualną. Tematem wybrzmiewającym w wielu wystąpieniach była, leżąca u podstaw profesjonalizmu, r e l a c ja.

William C. Gaventa (Conference Chair and Chair-Elected of The Board of Directors) w wystąpieniu powitalnym postawił najważniejsze i najodważniejsze bodaj pytanie, jakie zadano współczesnym specjalistom pracującym z osobami z niepełnosprawnością intelektualną. „Dostarczamy opieki i wsparcia w wielu różnorodnych kontekstach - powiedział W. Gaventa "Czy robimy to jednak w taki sposób, by nie przekraczać granic, szanować i wzmacniać więzy, ułatwiać osobom z niepełnosprawnością intelektualną bycie prawdziwymi członkami społeczności, w których żyjemy?". Pytanie o profesjonalizm powracało $\mathrm{w}$ sesjach plenarnych, $\mathrm{w}$ czasie obrad $\mathrm{w}$ równoległych sesjach tematycznych, podczas prezentacji posterowych i w rozmowach uczestników. W związku z tym, iż program konferencji był bardzo bogaty, pozwolimy sobie odnieść się do wybranych jego punktów.

Podczas sesji plenarnej 7 czerwca zgromadzonych gości, prelegentów i uczestników powitała Prezes Zarządu AAIDD (President, AAIDD Board of Director) Susan B. Palmer. Tego dnia wiodącym wątkiem prezentacji konferencyjnych była inkluzja, uwagę słuchaczy zogniskowały w głównej mierze dyskusje panelowe poświęcone wspomnianej problematyce. W sesji wzięli udział: Amy Hewitt (University of Minnesota) - moderator, Eric E. Jacobson (Georgia Council on Developmental Disabilities), Tom Kohler (Savannah Citizen Advocacy and Real Communities Initiative), Alison Barkoff (Bazelon Center for Mental Health Law), Basmat Ahmed (Real Communities Initiative and Altamyoz Community Building), Jessica Marie Mathis (Living Independence for Everyone). Dyskusja koncentrowała się wokół czynników wpływających na efektywność działań włączających oraz płaszczyzn i poziomów społecznej inkluzji. Wskazano przede wszystkim na procesualność omawianego zjawiska, mechanizmy aktywizujące i utrudnienia. Pytano 
o znaczenie pojęcia „włączająca społeczność”, o realny wymiar i zakres ról odgrywanych przez osoby $\mathrm{z}$ niepełnosprawnością intelektualną $\mathrm{w}$ grupie otwartej, o wartości, jakie osoba z ID wnosi do społeczności, w której żyje. Zastanawiano się, co może zaoferować ona innym, będąc tym, kim jest? Kluczowym punktem dyskusji stała się $\mathrm{w}$ tej części obrad o s ob a z niepełnosprawnością intelektualną oraz jej perspektywa postrzegania (rodzaju i płaszczyzn) wsparcia. Zwrócono uwagę na konieczność „wyjścia poza deficyty", uwzględniania faktycznych potrzeb człowieka z niepełnosprawnością, proponowanie rozwiązań $\mathrm{w}$ codziennych, typowych aktywnościach, oferowanie pomocy tam, gdzie jest ona oczekiwana i niezbędna. Dostrzeżono, iż prawdziwa inkluzja może być realizowana jedynie za sprawą międzyludzkich relacji, które mają zdolność wykraczania poza formalne ustalenia i definicje. Gotowość do wejścia w relację międzyludzką okazała się ważnym zasobem świadczącym o profesjonalizmie i jednocześnie elementem charakterystyki lokalnego środowiska włączającego. Budować społeczność włączającą można po pierwsze, uwzględniając relacyjny fundament inkluzji, po drugie - nie ignorując punktu widzenia, perspektywy osoby z niepełnosprawnością intelektualną.

Podczas drugiego i trzeciego dnia konferencji odbywały się sesje równolegle, w których poruszano m.in. zagadnienia:

- inkluzji, zmian w postrzeganiu pomocy osobom $\mathrm{z}$ niepełnosprawnością intelektualną,

- jakości życia i jej wskaźników,

- przygotowania do podjęcia zatrudnienia (Sesja A),

- kompetencji pracowników i konsultantów medycznych w relacji $\mathrm{z}$ osobą z niepełnosprawnością intelektualną, jakości kształcenia pracowników medycznych $\mathrm{w}$ tematyce niepełnosprawności intelektualnej,

- wsparcia starzejących się osób z niepełnosprawnością intelektualną i ich rodzin; roli pracowników służb społecznych,

- promowania dostępu do edukacji dla osób z wieloraką, złożoną niepełnosprawnością,

- działań na rzecz integracji, inkluzji we wspólnotach osób wierzących (Sesja B),

- współpracy specjalistów z różnych dziedzin, strategii działań wspierających, jakości usług,

- wykorzystania technologii $\mathrm{w}$ procesie wspierania i terapii, w zakresie rozumienia potrzeb osób z ID i członków ich rodzin, 
- znaczenia aktywności fizycznej, promocji zdrowia (R.A.M.P. Framework), edukacji włączającej,

- osób z niepełnosprawnością intelektualną w środowiskach wielokulturowych (Sesja C),

- dotyczące wykorzystania skali oceny potrzeb wsparcia SIS-A,

- udziału osób z ID w badaniach naukowych,

- seksualności osób z niepełnosprawnością intelektualną (Sesja D),

- innowacji w zakresie rozwiązań pomocowych,

- wykorzystania badań w praktyce, znaczenia w polityce, planowaniu; rola self-adwokatów (Sesja E).

Walorem sesji równoległych była różnorodność problematyki i możliwość zapoznania się z osiągnięciami badaczy nie tylko ze Stanów Zjednoczonych, ale i Australii, Brazylii, Tajwanu, Turcji, Ghany, Belgii i Włoch. Rezultaty badań na temat czynników jakości życia osób z niepełnosprawnością omawiali badacze: Marco Lombardi, Claudia Claes, Stijn Vandenelde, (University Gent), Luigi Croce (University Cattolica del Sacro Cuoro), Sofia Santos, Cristina Simões (Universidade de Lisboa).Sesji przewodniczył Robert Schalock, znawca problematyki QOL osób z niepełnosprawnością intelektualną.

W sesji plakatowej, która miała miejsce w kolejnym dniu konferencji (7 czerwca), zaprezentowano 163 postery. Prace udostępnione zostały w następujących sekcjach tematycznych: starzenie się, diagnozowanie, autyzm, edukacja, zatrudnienie, rodzina, zdrowie i samopoczucie, polityka i prawo, jakość życia, samostanowienie (ang. self-determination), społeczne włączenie, technologie, szkolenia (ang. workforce). Sesja posterowa okazała się użyteczną formą zademonstrowania wyników badań, założeń projektów naukowo-badawczych i innowacyjnych na rzecz osób z niepełnosprawnością intelektualną.

Jako uczestnicy projektu „System elektronicznego wspomagania samodzielności życiowej osób z niepełnosprawnością intelektualną" (/IS-2/105/ /NCBR/2015) mieliśmy okazję wziąć udział w sesji plakatowej i przedstawić doniesienie z badań realizowanych przez konsorcjum: Stowarzyszenie Na Tak, Instytut Chemii Bioorganicznej Polskiej Akademii Nauk - Poznańskie Centrum Superkomputerowo-Sieciowe, Uniwersytet im. Adama Mickiewicza w Poznaniu.

Celem projektu jest opracowanie innowacyjnego rozwiązania wspierającego samodzielność życiową osób z lekkim i umiarkowanym stopniem niepełnosprawności intelektualnej w oparciu o wykorzystanie nowocze- 
snych technologii informacyjno-komunikacyjnych, tj. telefony komórkowe i internet. Rozwiązanie to (aplikacje zainstalowane w smartfonie) ma być zastosowane $\mathrm{w}$ naturalnym środowisku życia osób $\mathrm{z}$ niepełnosprawnością: w domu, w pracy, w placówkach aktywizacji społecznej i zawodowej, w społeczności lokalnej. Główne założenie innowacji opiera się na przekonaniu, iż zindywidualizowane, dostosowane do psychofizycznych możliwości odbiorców rozwiązania teleinformatyczne mogą niwelować utrudnienia $\mathrm{w}$ ich samodzielnym funkcjonowaniu, $\mathrm{w}$ różnych obszarach życia w taki sposób, aby optymalnie wykorzystać możliwości oraz potencjał psychospołeczny i funkcjonalny. Wyposażenie osób z niepełnosprawnością intelektualną w specjalizowane aplikacje ma w perspektywie długofalowej wzmocnić ich potencjał, tak by mogły osiągnąć wyższy poziom funkcjonowania w życiu społecznym i zawodowym. Długofalowo - zaproponowane rozwiązanie może przyczynić się do wzrostu aktywności tej grupy społecznej, włączając ją w główny nurt życia społecznego.

Bazę budowy rozwiązań teleinformatycznych dla osób z niepełnosprawnością intelektualną stanowią wyniki badań własnych, które umożliwiły określenie kluczowych obszarów wsparcia w ich codziennym funkcjonowaniu (na podstawie kryteriów statystycznych, funkcjonalnych, podmiotowych, odpowiedzialności i bezpieczeństwa), a także pozwoliły na wyłonienie siedmiu archetypów (siedmiu grup badanych o podobnych cechach pod względem samodzielności). Opis każdego z nich reprezentuje szerokie spektrum potrzeb, możliwości, punktów widzenia i osobistych wartości dorosłych osób z lekkim i umiarkowanym stopniem niepełnosprawności intelektualnej. Metoda archetypów maksymalizuje szanse na konstrukcję precyzyjnych odpowiedzi teleinformatycznych na różnorodne wymagania dotyczące wspierania samodzielności życiowej tych osób opracowywanych w kolejnych zadaniach.

Przygotowany przez nas poster prezentował możliwości aplikacji w procesie wspierania niezależnego życia na przykładzie populacji 65 osób z lekką i umiarkowaną niepełnosprawnością intelektualną zamieszkujących województwo wielkopolskie. Przedstawiliśmy, w jaki sposób poziom niezależności, zakres aktywności i możliwości przekładają się na zapotrzebowanie na rozwiązanie oparte na TIK, które może pomagać osobie z niepełnosprawnością $\mathrm{w}$ osiągnięciu pożądanych celów. W 2015 r. przygotowaliśmy zbiór danych dotyczących wyżej wspomnianej populacji i podjęliśmy analizy wpływu tych danych na proces opracowywania rozwiązań wspomagających technologię. Przy użyciu skali SelFind - Life Independen- 
ce Scale, która została wypełniona przez terapeutów i rodziców przebadano 65 osób z niepełnosprawnością intelektualną.

Skala Samodzielności Życiowej SelFind została stworzona przez zespół specjalistów ze Stowarzyszenia Na Tak i Uniwersytetu im. Adama Mickiewicza w Poznaniu pod kierunkiem prof. Zbigniewa Woźniaka, z myślą o osobach z lekkim i umiarkowanym stopniem niepełnosprawności intelektualnej. Jest to narzędzie wielowymiarowe. Pozwala ocenić aktualny poziom samodzielności badanej osoby w dziesięciu obszarach:

1) orientacja w otoczeniu,

2) orientacja w czasie,

3) samodzielność w wykonywaniu zadań,

4) samodzielność $w$ komunikowaniu się,

5) samodzielność w zakresie samoobsługi,

6) samodzielność $w$ domu,

7) samodzielność w dbaniu o higienę osobistą i zdrowie,

8) samodzielność ekonomiczna,

9) samodzielność gospodarcza,

10) funkcjonowanie psychospołeczne.

Skalę można wykorzystywać zarówno w ocenie funkcjonowania osoby w placówce (np. Warsztaty Terapii Zajęciowej, Środowiskowy Dom Samopomocy, Dom Pomocy Społecznej), jak i poza nią (np. przestrzeń handlowo-usługowa), a także w domu rodzinnym czy w mieszkaniu wspomaganym. Narzędzie pozwala na precyzyjne określenie możliwości i ograniczeń; opisanie nie tylko trudności, ale też umiejętności posiadanych i wykorzystywanych przez osobę w różnorodnych sytuacjach życiowych. Wypełnianie skali wspólnie $\mathrm{z}$ badanym umożliwia gromadzenie informacji na temat poziomu i zakresu samodzielności, buduje również jego samoświadomość. Szerokie ujęcie samodzielności może pomóc w zebraniu danych będących podstawą wspierania autonomii osób z niepełnosprawnością intelektualną w wielu aspektach codziennego życia.

Wykorzystując metodę cienia (ang. shadowing method), obserwowano, jak 13 osób z niepełnosprawnością intelektualną używa smartfonów, natomiast $\mathrm{w}$ trakcie badań $\mathrm{w}$ terenie przeprowadzono warsztaty fokusowe (ang. focused workshops) z terapeutami i uczestnikami placówek wsparcia (łącznie: 24 osoby) oraz warsztaty Walt Disney (ang. Walt Disney Method), w których wzięło udział 15 terapeutów, 17 rodziców i 5 wolontariuszy (łącznie 37 osób).

Zakończenie budowy pierwszej wersji systemu planowane jest na koniec 2016 r. Użyteczność zaprojektowanego rozwiązania wspierającego 
niezależność i samodoskonalenie zostanie zweryfikowana w 2017 r. w grupie 15 osób z lekką i umiarkowaną niepełnosprawnością intelektualną.

W kolejnym dniu konferencji, podczas panelu wystąpili reprezentanci różnych środowisk: Ann P. Turnbull, (FAAIDD, Kansas University), Trace Haythorn (Association for Clincal Pastoral Education), Martha Haythorn (Partnerships for Success, Decatur High School), Kellie Roberts (rodzic), Meghan Burke, (University of Illinois at Chicago), Bernard Baker (People First of Georgia). Prelegenci starali się dać odpowiedź na pytanie o źródła i przejawy profesjonalizmu. Podkreślili znaczenie wrażliwości interpersonalnej, umiejętności współodczuwania (ang. compassion) oraz otwartości w relacjach $\mathrm{z}$ drugim człowiekiem. Stwierdzono, iż wymienione właściwości obok kompetencji merytorycznych, w tym wiedzy, stanowią o profesjonalizmie. Fundamentalnym elementem profesjonalizmu okazała się wiara w sensowność i powodzenie terapii, pozytywne i pełne troski nastawienie zarówno wobec dziecka, jak i rodzica. Dla tego drugiego bycie traktowanym podmiotowo: w procesie diagnozy jako „ekspert od dziecka”, w terapii jako partner w działaniu okazało się nie tylko wyznacznikiem postaw wobec dziecka i jego niepełnosprawności, ale i podstawą dla budowania perspektywy jego rozwoju. Profesjonalizm przejawia się także $w$ taktownym sposobie przekazywania diagnozy, komunikowania się $\mathrm{z}$ osobą $\mathrm{z}$ niepełnosprawnością intelektualną, postawach wobec niej i jej rodziny. Zgodnie stwierdzono, iż stosunek specjalisty do osoby $\mathrm{z}$ niepełnosprawnością intelektualną skutkuje tym, jak będzie ona odbierana przez społeczność. Z kolei jego elastyczność w relacji, dążenie do odnalezienia płaszczyzn porozumienia i najprościej mówiąc, wiara $\mathrm{w}$ powodzenie podejmowanych działań, to istotne kompetencje, które - szczególnie w opinii rodziców - składają się na profesjonalizm. Ważnym głosem w dyskusji były też wypowiedzi osób z niepełnosprawnością, w których jasno wybrzmiała potrzeba bycia traktowanym w sposób adekwatny do wieku metrykalnego i jednocześnie partnerski (,,jestem tu, mam więcej niż 50 lat i nie chcę być traktowany jak dziecko"). Jedna z matek wskazała, iż umiejętność dostrzegania przez specjalistów mocnych stron w rozwoju dziecka, nie tylko koncentrowanie się na deficytach, przesądza jej zdaniem o jakości pracy z nim. Specjaliści dostrzegli, iż krytyczna autoewaluacja stanowi zarówno ogromne wyzwanie, ale może być też oznaką profesjonalizmu. Refleksja nad własnym działaniem umożliwia korektę błędów, twórczy namysł - dostosowanie do rzeczywistych potrzeb osoby, planowanie działań - adekwatne wsparcie. 
Konferencji towarzyszyła "Silent Auction”, z której dochód przeznaczono na potrzeby działań organizacji People First of Georgia oraz promocja wydawnictw na temat niepełnosprawności intelektualnej (AAIDD, NADD $\mathrm{i}$ in.). Na spotkanie $\mathrm{w}$ Atlancie zostali też zaproszeni przedstawiciele podmiotów działających na rzecz osób z niepełnosprawnością intelektualną w Stanach Zjednoczonych. Na stoiskach wystawienniczych można było znaleźć materiały prezentujące m.in. organizacje o profilach medycznych, edukacyjnych, społecznych $i$ in.

Wydarzeniami towarzyszącymi konferencji były spotkania grup roboczych AAIDD, zjazd rodzin osób z niepełnosprawnością intelektualną oraz forum duchowości i religii zorganizowane przy współpracy z The North Georgia CPE Consortium Group. Problematyka sympozjum dotyczyła rozumienia czym jest niepełnosprawność intelektualna, wsparcia i opieki duchowej dla osób z niepełnosprawnością intelektualną w szpitalach, osób doświadczających bezdomności, funkcjonujących we wspólnotach oraz przebywających $w$ rodzinie.

$\mathrm{Na}$ zakończenie organizatorzy przygotowali niezwykle sympatyczną niespodziankę - krótki film nawiązujący do rozważanej tematyki, w którym pojawia się wiele odpowiedzi na pytanie o profesjonalizm, udzielanych przez uczestników tegorocznej konferencji w Atlancie. 